\title{
A DECIZIONIZMUS MEGZABOLÁZÁSA
}

\author{
Gyulai Attila \\ (Társadalomtudományi Kutatóközpont, Politikatudományi Intézet/Nemzeti Közszolgálati \\ Egyetem, Eötvös József Kutatóközpont, Politika- és Államelméleti Kutatóintézet)
}

A recenzió beérkezett: 2019. október 22. - véglegesítve: 2019. október 22.

(Karácsony András: Döntés és hagyomány. Budapest, Századvég Kiadó, 2019.)

A politika sajátszerüségének gondolata szinte kézzelfogható módon előtérbe került az utóbbi időben. Mind a gyakorlatban, mind pedig az elméletben teret nyert az az elképzelés, hogy a politika autonóm, és múködését másból levezetve nem érthetjük meg, csakis a rá jellemző sajátos törvényszerüségek felől. Ebből következően a politika megítélésében, a politikai cselekvések értékelésében sem fordulhatunk más mércéhez, mint ami a politika sajátja. Természetesen nem új gondolatról van szó, az erről szóló vita elválaszthatatlanul a politikához tartozik, hiszen a politika lényegéről szól. Csakhogy mintha lennének olyan korszakok, és talán a jelenlegi is ilyen, amikor a vita nem pusztán politikai kérdések körül zajlik, hanem éppen a politika természete kapcsán élesedik ki. Amikor olyan döntések születnek, amelyek túllépnek a napi politikai rutin keretein és magukra a keretekre, a döntések feltételeire irányulnak. Vagyis amikor nem az a kérdés, hogy egy-egy politikai döntés megfelelő-e, hanem az, hogy mi tehet egy döntést megfelelővé. A politika sajátszerűsége praktikusan a döntésen keresztül válik láthatóvá, és ez teszi a politikai gyakorlat és az elmélet felől is aktuálissá Karácsony András legutóbbi, Döntés és hagyomány címü könyvét, amely a döntés fogalmán keresztül idézi fel a politika mibenlétének kérdését, szűkebben pedig a politika és a jog közötti határ átjárhatóságának problémáját.

A kötet egyrészről a döntésprobléma gondolkodástörténeti előzményeit követi végig, másrészt tematikus fejezetekben fejti ki a szerző felfogásának lényeges építőelemeit. Az Előszó elhatárolja a döntésprobléma különböző megközelítéseit, és a pszichológia, közgazdasági és egyéb irányoktól ellépve a politika és a jog területére irányítja a figyelmet, ezen belül is kiemelve Carl Schmitt és Niklas Luhmann szerepét a kérdés tárgyalásában. A későbbiekben érdemes lesz visszatérni arra, hogy mi a jelentősége épp e két gondolkodó kiemelésének, ahogy arra is, hogy a döntés fogalma már az első oldalon a decizionista felfogás mentén fogalmazódik meg. Az 1. fejezet a szellemi kontextust mutatja be,

Politikatudományi Szemle XXVIII/4. 155-160. pp. (C) Társadalomtudományi Kutatóközpont https://doi.org/10.30718/POLTUD.HU.2019.4.155 
külön kitérve az eszmetörténeti, a politikai, a jogi, valamint a döntéselméleti háttérre - tovább részletezve a kötet saját felfogásának megalapozását. A 2-6. fejezetek néhány szerző köré szervezve tárgyalják a döntés felmerülését, kiemelt vagy mérsékelt szerepét, illetve semlegesítését az egyes elméleti megközelítéseken belül, sorra véve Schmitt, Luhmann, Habermas, Rawls, valamint a fenomenológiai hagyomány döntésfogalmát. A könyv második nagyobb egysége egy-egy fejezetet szentel a döntés összefüggésének a hagyomány, az emlékezés, valamint a felelősség problémáival. Ez utóbbi három fejezetben összpontosul Karácsony András saját megközelítésének lényege, az itt olvasható gondolatmenetből válik világossá, hogy korábban miért éppen az említett gondolkodástörténeti előzmények kaptak szerepet, és azokhoz képest miként rajzolódik ki a szerző saját döntésfelfogása. Meg kell említeni, hogy a szellemi kontextus és a recepció elemzése során - olvasóinak ez aligha újdonság - Karácsony András elsősorban a német hagyományra támaszkodik, ami Schmitt, Luhmann vagy Habermas esetében persze nem meglepő, a Rawls-fejezet esetében viszont a fősodorhoz képest a megszokottól eltérő szerzők beemelését jelenti.

Schmitt kiemelt szerepe természetesen nem meglepő: a politika- és jogelméletben egyre erőteljesebb a schmitti decizionizmus szerepe, és a hazai szakirodalmat tekintve Karácsony András korábbi munkái ezen a téren már eddig is iránymutatóak voltak. Csupán az elmúlt években megjelent nagyobb publikációkat említve, a döntés fogalma központi jelentőségú a szerző Jogelméleti elóadások című kötetében, Carl Schmittről pedig önálló - a politikai teológiára koncentráló - monográfiája szól (Karácsony, 2016 és 2017). Schmitt munkásságát tekintve Karácsony jelen kötete jogosan indul ki a német szerző 1912-es Gesetz und Urteil címú múvéből, hiszen ebben a bírói döntésre fókuszáló munkában már fellelhetőek a későbbi politikaelméleti decizionizmus alapelemei. Csakhogy, mutat rá Karácsony András, a decizionizmus rögtön gyanúba keveredik, ha a jog területét elhagyva a politikán belül látszik érvényesülni, és korántsem csak arról van szó, hogy Schmitt mit és miként igazolt a levezethetetlen döntés fogalmán keresztül az 1930-as évek Németországában, hanem a politikai döntés eleve adott önkényességének tételezéséről (25.; 46.). Ha ugyanis a bírói döntés egyedi aktus, amely nem igazolható a gyakorlathoz képest külső elvekhez mérve, akkor a politika területére lépve máris e recenzió elején jelzett problémába ütközünk. Persze nem mellékes, hogy 1912-ben Schmitt még számos elemet így is megőrzött saját kora neokantiánus jogfelfogásából (Schmitt, 1969), és számos további lépést tett még meg, mire a döntés fogalma az 1920-as évek elejére politikaelméleti és politikai tétet kapott volna nála. A Schmittről szóló fejezetben Karácsony András is ezt a változást követi végig, hogy a politikai döntésnek a kivételes állapotban megmutatkozó tiszta típusáig jusson el. A könyv Schmitt-fejezete és helye a munka gondolatmenetében különösen lényeges, és korántsem csupán amiatt, mert a schmitti 
szuverén ma már megkerülhetetlen a döntésproblematika szempontjából. Karácsony tulajdonképpen a schmitti módszert követve a döntés szélső fogalmát ragadja meg Schmitten keresztül, azt a határt igyekszik bejárni, ahol a döntés a maga legtisztább formájában, a semmiből érkezve mutatható fel, hogy ehhez képest derüljön ki a további fejezetekben tárgyalt felfogások által nyújtott hozzájárulás. Valójában Schmitt nem a Karácsony által tárgyalt döntésfogalom kimerítő modellje, pozíciója közelebbről nézve nem schmittiánus decizionista, számára inkább van szó módszertani eljárásról, amely lehetővé teszi egy olyan döntésfogalom kidolgozását, amely megtartja a döntés egzisztenciális jelentőségét, de feltételezi, hogy lehetséges felfedezni olyan mércéket, amelyek a felelősség felvetését is lehetővé teszik. Innen nézve nyerik el jelentésüket a döntésfogalom recepciójával kapcsolatos további fejezetek. Schmitt és Rawls között olyan utat jár be a könyv, amely a döntés totalitásától a döntés semlegesítéséig vezet, és a tét az, hogy valóban létezik-e az a pozíció, amelyet e kettő között Karácsony András keres.

Ahogy a szerző is utal rá, Schmitt mellett a könyv másik főszereplője Luhmann (13.). A két gondolkodó kapcsolata a döntés elkerülhetetlen, kiemelt szerepében ragadható meg, de ebben az esetben a különbségek meghatározóak. Mert bár a döntésben mindig jelen van az önkény és a levezethetetlenség, a luhmanni társadalomelmélet a decizionizmus határait is láthatóvá teszi. Az egyébként ugyancsak a semmiből érkező kötelező döntések egyrészt nem személyhez kötöttek, másrészt nem totalizálók, vagyis a belőlük következő politika nem számolja fel a pluralitást, sokkal inkább a differenciálódáshoz kapcsolódik (Thornhill, 2007). Karácsony András ezt úgy magyarázza, hogy a luhmanni felfogás a kontingencia csökkentése és a komplexitás fenntartása kettősségére épül (67.). Luhmann nyomán fogalmazódik meg ugyanakkor az az alapvető gondolat, hogy a döntés alapja nem más, mint önmaga lehetetlensége. Ez a paradoxon azt mondja ki, hogy dönteni akkor kell, amikor nem lehet dönteni (66.), vagyis a döntés helye ott van, ahol az előzetesen adott nem jelöli ki a követendő irányt, amikor a döntés nem adódik, hanem meg kell hozni. Nem véletlen, hogy a jog világának programozó és programozott döntés közti luhmanni különbségtétele (84.) alapján az igazi döntés (66.) bizonyos mértékig valóban visszavezethetô a schmitti kiindulóponthoz. Mégpedig pontosan azért - és itt ismét a határ problémája jelentkezik -, mert a programozó döntés kivezet a jog világából és a politika felé mutat (86.). Mégis, éppen ezen a nyomon juthatunk el a felelősség kérdéséhez, amit Karácsony pusztán Luhmann alapján nem tart egyértelmúen kezelhetőnek, de a felelősség megállapításáról szóló döntés helyét legalábbis kijelöli.

Némi leegyszerűsítéssel mondható, hogy a következő - Habermas és Rawls elméletét - tárgyaló fejezetek az ellenpozíciót mutatják be, vagyis olyan megközelítéseket, ahol a döntés schmitti és luhmanni kiélezettsége nem egyszerúen háttérbe szorul, hanem feloldódik egyfelól a tanácskozás konszenzusá- 
ban, másfelől pedig az igazságosságban. Csakhogy Karácsony András tárgyalásmódja nem ilyen élesen megkülönböztető. Miközben láthatóan van jelentősége a decizionista kiindulópontnak, mert a szerző onnan fogalmazza meg saját álláspontját, elemzésére jellemző, hogy Habermas és Rawls esetében sem egyszerűen az ellenpontot, hanem a megfontolható érveket keresi. Ugyanakkor erre a két fejezetre jellemző leginkább, hogy a döntésfogalom olykor háttérbe szorul a tárgyalt szerzők tágabb elméleti pozíciójának bemutatása és elemzése mögött. Ezt persze az indokolja, hogy a döntés messze nem annyira közvetlenül adódó probléma Habermas vagy Rawls számára, mint Schmitt vagy Luhmann esetében, pontosabban egy negatív módon adódó probléma, így a fogalom itt sokkal inkább összehasonlításként, illetve további szerzőkkel való összevetés útján és gyakran a felmerült kritikák tárgyalásaként kerül elő. Habermas esetében a fő kérdés természetesen az, hogy a konszenzusra orientált deliberációban marad-e helye a döntésfogalomnak, hogy „értelmes-e a döntés fogalmát használni teljes körű egyetértés esetén, amikor nincs senki, akivel szemben a döntést érvényesíteni kellene" (112.), illetve ehhez vezetően az, hogy a habermasi tanácskozás megmarad-e procedurális előfeltételnek vagy szubsztantív előírássá alakul át. Karácsony András olvasatában utóbbi kérdésre a válasz az, hogy a deliberációval szemben támasztott elvárások tartalmi elvként hallgatólagosan is az eljárás formalitása fölé kerekednek, mintha - tehetjük hozzá - mégiscsak született volna döntés azzal kapcsolatban, hogy mely elveket kellene legitim szervezőelvnek tekinteni. Csakhogy a tanácskozás személytelen folyamata nem teszi megragadhatóvá a döntést, ahogy a szuverenitás is szinte eltûnik, amint az államtól a társadalom szférájába kerül át (106.). Ezzel pedig láthatatlanná válik, mert semlegesítődik a politikai döntés mögött mindig feltételezhető kényszer is, ami Karácsony András megközelítésében nem egyszerúen az antipolitika kockázatát hordozza, hanem a jog önállóságának felszámolását a politika felől (107.; 111.).

Bár a Habermas-fejezet előrevetíti, hogy a rawlsi megközelítés határozottan a szubsztantív felfogást követi a deliberáció tételezett formalitásával szemben (100.), az elemzés során sokkal inkább azok az elemek emelkednek ki, amelyek a semlegesítés gesztusában egymás mellé helyezik a két szerzőt. Ebben az értelemben tehát érvényesül Habermas és Rawls ellenponti szerepe a könyv gondolatmenetében, utóbbi esetében egészen odáig, hogy megkérdőjeleződik a döntés szerepe az eredeti helyzetből való átlépés során (119.). Karácsony András döntően a német Rawls-recepcióra támaszkodó elemzése végső soron arra hívja fel a figyelmet, hogy a filozófiai igazságosságelmélet és a liberalizmus felé való politikai elmozdulás között, a szubsztantív törekvéseket megtartva, a döntést alapvetően jellemző kontingencia (ami a könyv egyik kiindulópontja) nem értelmezhető. Ezzel pedig eljutunk a döntés decizionista felfogásától az ellentétes pozícióig, ahol a döntés valójában a döntés elkerülését, intézményesített felszámolását jelenti. Talán nem véletlen, hogy a Rawls-fejezet egy meg- 
lehetôsen radikális szerzői fordulattal két olyan gondolkodóra (Derrida és Lyotard) támaszkodva zárul, akik kifejezetten tagadták a jog és igazságosság összeilleszthetőségét, és a jogot az erőszakra, illetve az elkerülhetetlen jogtalanságra vezették vissza.

A döntés fogalmát egyik végponttól a másikig eljuttatva természetesen felmerül az a kérdés, hogy mi lehet mégis a döntés mércéje és igazolása. Miként támasztható alá egy döntés, ha nem fogadjuk el, hogy semlegesíthető lenne, miközben a cél mégiscsak az, hogy igazolható, vagyis lényegi önkényességével együtt is behatárolható legyen? A szerző erre adott válaszában játszik fontos szerepet a fenomenológiai hagyományról szóló rész, ahol Karácsony András a racionalitás és a szokások szerepét tárgyalja Alfred Schütz és Harold Garfinkel nyomán. A racionalitás az, ami tradicionális - írja (134.), felvetve, hogy a döntés racionalitása nem csak abban a keretben értelmezhetô, ahogy a racionális döntéselméleti paradigma közelít a kérdéshez. A döntés racionalitása utóbbival szemben a mindennapiság kontextusába ágyazott interakciókban érhető tetten, ahol a cselekvők a szokások erejére támaszkova fogadnak el bizonyos mintákat és szabványokat (133.). Az életvilágban nem pusztán egyének döntéseit figyelhetjük meg, hanem együtt cselekvők közös produktumát, amelyet a közösen követett - és ezáltal elismert - szokások tartanak egyben, amelyek a döntéseknek teret adnak, de meghatározott keretek között is tartják őket. Az e szakaszban olvasható elemzésnek nem célja, hogy szubsztantív módon megjelölje a döntések kereteit, bár olvashatunk a középérték felé való orientálódásról (134.). A racionalitás tulajdonképpen azzal kapcsolatos, amire már a Luhmann-fejezet is utalt, hogy a döntések valódi döntések legyenek, érdemi alternatívák közötti, nem elöre programozott választások, amelyek ugyanakkor nem számolják fel az együttélés kereteit korlátlan önkényességükkel. Ez az a pont, ahol a kötet programja igazán explicit érveléssé alakul át.

A könyv egészével azonos címet viselő Döntés és hagyomány címú fejezet a szokások meghatározó szerepét és fenti értelemben vett racionalitás szerepét megtartva azt hangsúlyozza, hogy a hagyományok nem zárják ki a döntést, sőt, hogy a döntésnek megkerülhetetlen szerepe van a hagyományok érvényesülésében. A hagyományok közötti választás, illetve a hagyomány választása ugyanakkor szemben áll a kontextusokon túllépni törekvő döntéssel, vagy ahogyan Karácsony fogalmaz, a valóságot zárójelbe tévő döntésimádattal (147.). A politikai cselekvések tehát egyrészről nem "programozottak”, nem maradéktalanul levezethetők korábbi - ugyancsak programozott - döntések sorozatából, de nem is korlátlanok. Ahogy a döntés és a felelősség problémájával foglalkozó utolsó fejezetben olvasható, még a schmitti szuverén semmiből érkező döntése sem áll teljes mértékben kívül minden kontextuson, mert még a decizionizmus e formája is az adott kontextushoz képest nyeri el jelentését (177.). Karácsony András ezt - és a döntés által befolyásolt emlékezés tárgya- 
lását - követően a felelősség kérdése kapcsán lép igazán közel a kortárs politikai kontextushoz. A döntés luhmanni paradoxona - dönteni ott kell, ahol nem lehet dönteni - itt pozitív kifejtést kap, amennyiben összekapcsolódik egymással szabadság, döntés és felelősség hármasa (163.) egyértelmúen szembe helyezkedve minden olyan - a korábbi fejezetekben tárgyalt - törekvéssel, amely azért és olyan módon semlegesíti a döntést és oldja fel a döntésért viselt felelősséget, hogy felszámolja a személyes elem szerepét (164.), legyen az eljárás, levezetett döntés (ami tehát valójában nem döntés) vagy a normák által maradéktalanul determinált választás. A kortárs kontextust illetően a szerző a demokrácia és a jogállam feszültségét állítja középpontba, határozottan kritizálva utóbbi elem felelósségét abban, hogy a mechanizmus felértékelésével leértékeli a személy szerepét - ezen a ponton visszatérve a schmitti felfogás egyik alapvonásához (170.; 178.). A döntés tehát Karácsony Andrásnál normatív tartalmat kap, amennyiben a döntés értéke abban áll, hogy fenntartja a lehetőségek és következmények pluralitását (171.), és a politika világát nem redukálja személytelen és ezért végső soron számon kérhetetlen automatizmusokra. A hagyomány és a szokások szerepe mindebben az, hogy ezek sem monolit és változtathatatlan elemként jelennek meg, hanem önmagukon belül is felmutatják a pluralitást és a választás lehetőségét, sőt, a döntéshozatal kötelességét.

A döntés - érvel Karácsony András - mindig kockázatot hordoz magában. Mivel a döntés önmaga lehetetlenségéből következik, aki dönt, saját politikai létezését is kockáztatja, hiszen a döntéshozó nem támaszkodhat eleve elrendezett alternatívák által adott biztosítékokra. A decizionizmus pedig, amenynyiben önkényes, de mégis határos, a politika területén érvényesülve nem a döntés korlátlanságát támasztja alá, hanem ezzel éppen szemben azáltal igazolja a politikai cselekvést, hogy megköveteli a felelösségvállalást. Karácsony András könyve határozottan állást foglaló érvelés e pozíció mellett, amelyben egyszerre van jelen a decizionizmus konzervatív értelmezése és a döntés melletti általános kiállás, mint ami lehetővé és elszámoltathatóvá teszi a politikát, olyan mércét ajánlva ehhez, amely nem a politikán kívülről, hanem annak szabályait szem előtt tartva fogalmazódik meg.

\section{IRODALOM}

KarácsonyAndrás (2016): A jogtudomány teológusa. Carl Schmitt politikai teológiája. Attraktor.

Karácsony András (2017): Jogelméleti elöadások. ELTE Eötvös Kiadó.

Schmitt, Carl (1969): Gesetz und Urteil. C. H. Beck.

Thornhill, Chris (2007): Niklas Luhmann, Carl Schmitt and the Modern Form of the Political. European Journal of Social Theory, 10(4). 499-522. DOI: 10.1177/1368431007075966 